\title{
Computer Application Learning Model Based on Brain Gym to Improve Student Learning Outcomes of PKOM Dehasen University Bengkulu
}

\author{
Mesterjon $^{1}$, Suwarni ${ }^{2}$, Diah Selviani ${ }^{3}$ \\ ${ }^{1,2,3}$ Universitas Dehasen Bengkulu, Indonesia \\ mesterup@yahoo.co.id,suwarni@unived.ac.id,diah.selviani@unived.ac.id
}

\begin{abstract}
This study aims to produce a brain exercise-based computer application learning model to improve learning outcomes of PKOM students at Dehasen University Bengkulu. This type of research is a development research that produces a learning model based on brain exercise in understanding the concepts of the basics of using Ms. Excel whose syntax is a) introduction, $b$ ) core activities include (i) the problem giving phase, (ii) the investigation phase, (iii)) the group discussion phase, (iv) the class discussion phase, (v) the application phase, $c)$ the closing phase. The development design according to Plomp (1999) consists of five phases, namely: initial investigation, design / design, construction / realization, testing, evaluation \& revision and implementation. The subjects of this study were students of the first semester of Computer Education at Dehasen University Bengkulu for the 2019/2020 academic year with 18 students. Based on the results of the research, it can be concluded that: 1) from the results of the trials conducted 2 times which were limited trials in this study it can be concluded that all aspects are determined to state that the learning model and all the learning tools developed are practical and effective has been fulfilled then the development cycle to get a practical and effective learning model has ended. But even though all the criteria are met, there are some revisions that must be made to get the final prototype. Revisions made related to the use of language in model books and student activity sheets. After the revision was carried out, a final prototype was obtained, namely a valid, practical, and effective computer-based learning model for brain exercise.
\end{abstract}

Keywords learning model; computer application; brain gym

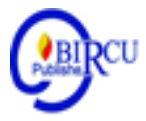

\section{Introduction}

Regarding mastery of science and technology, computer application courses have a role and are a very important subject in utilizing current technology both in education systems throughout the world, especially in Indonesia. Learning computer applications generally focuses more on basic skills to use and make the most of them. Students are more likely to memorize or imitate what their lecturers have done so that their ability to optimize their brain is very lacking.

Likewise in the learning process of computer applications at Dehasen University Bengkulu. Based on the results of direct observation, it turns out that the lecturers of computer applications on the campus also face this phenomenon. Students are not motivated to use computers optimally because there are still many students who come from remote 
areas and just discovered and used computers when they first entered college. Given the potential that there are students of PKOM Dehasen Bengkulu University students are very heterogeneous because of the foundation's regulations that are not at all in admitting students by means of academic selection so that the lecturers of computer applications at Dehasen University Bengkulu are very difficult in dealing with situations like this, because there are students who have average grades. Report cards are counted from class X to class XII, the average NEM has reached above 70 and some are below 70. This is evident from the fact that in the field students continue to imitate only. So that the results of both the quiz value and the daily value are very heterogeneous, some reach a value of 100 and some only get a value below 20 .

In computer application lessons experienced by lecturers and students at Dehasen University who still apply learning models that are less relevant to the characteristics and learning objectives. Lecturers are still guided by computer application printed books without paying attention to the atmosphere of the classroom climate, student emotions and actual learning objectives.

The current or ongoing implementation of computer application learning conditions has not implemented brain exercise-based learning that optimizes the main functions of the brain and connects learning material with the problems of student daily life in an effort to optimize the main functions of the brain and an attractive classroom climate so that students understand concepts and solve problems, and utilize social interaction patterns in organizing student learning to be actively involved in reconstructing computer application knowledge through brain exercise-based learning. This encourages researchers to develop a learning model that is expected to guide computer application learning.

When students are faced with a pattern of solving a problem, understanding and explaining a certain situation, or reflecting on a process, they need a rule or relationship that underlies the problem. To achieve this goal, they must identify the structure they have obtained in previous activities and use it in subsequent activities (Mega Teguh Budiarto, 2006: 4).

\section{Review of Literatures}

Eric Jensen (2011), why is it now time to make a shift in thinking? Exercise about what is functioning now is both very compelling and comprehensive. We are all natural learners, children who fail and schools that fail are indicators of a wrong system not a wrong brain, if our students are given an optimal learning environment for learning then good graduate rates will increase, learning difficulties and the problem of discipline decreases, the pleasure of learning springs, in short the creation of an organization around the way the brain learns best naturally, are the simplest and most important educational reforms that must be initiated. In fact, none of these reforms provide the most favorable investment returns of time, energy and money than developing an approach to brain exercise-based learning.

Eric Jensen (2011: 14), the brain is the most important organ we have. The number of cells varies greatly among humans, but it is generally said that a person's brain contains between 50 and 100 billion nerves. Brain sizes and weights vary widely, averaging $1.36 \mathrm{~kg}$ to $1.8 \mathrm{~kg}$. Albert Einstein, who developed the theory of relativity, had an average sized brain. For comparison, a monkey has about 10 percent of human nerves, a mouse has only 5 million brain cells and flies has 100,000. Individual cells do not make us intelligent, they are connections that make us intelligent, when linked together, and the number of connections in our brains is estimated to be around 100 trillion or more. 
According to Lehawati (2020) The emotional brain is just as involved in thinking as the reasoning brain is. In a sense we have two brains, two minds and two different intelligences: rational intelligence and emotional intelligence. Goleman also emphasized that a person's success in life is determined by both not only intellectual intelligence, but also emotional intelligence. Thus, intellectuality cannot work at its best without emotional intelligence. The learning model used is less effective and less attractive to students, not in accordance with the needs and character of students. Therefore, an appropriate learning model is needed in delivering news text material to students so that the competencies that students must meet are achieved well.

According to Simanjuntak (2020) the teacher is a very important factor in determining the success of the learning process, therefore the teacher must be able to increase student learning motivation so that students play an active role in the learning process so that they are expected to achieve good quality education. Khairani (2020) stated that teacher must be more careful in developing strategies, methods, and skills so that learning objectives can be achieved and implemented properly. Natural Science in elementary schools is one of the main subjects in the educational curriculum.

Eric Jensen (2011: 14), all sensory input will be sorted, prioritized, processed, stored or discarded at one subconscious level when processed by the brain. Every second a nerve can send 20 to 2500 impulses or stimuli. If we divert this transmission ability with the number of nerves we have, we will reduce the innumerable potential of human learning.

Based on these descriptions, the authors want to conduct development research entitled "Learning model of brain exercise-based computer applications to improve learning outcomes of PKOM Dehasen University students in Bengkulu" so as to produce a brain exercise-based computer application learning model to improve learning outcomes of PKOM Dehasen University students.

\section{Research Methods}

Based on the research questions formulated in this study, this type of research is development research with limited trials (Sugiyono, 2011: 314). The type of research used is development research, the research to be carried out is development research because research is carried out to develop and validate the products used in education and learning in the form of materials, media, learning tools and / or strategies, evaluation tools, and so on to solve educational problems, increase the effectiveness of PBM in the classroom / laboratory, and not to test theories (Wahyu Widada, 2007).

The development design according to Plomp (1999), consists of five phases, namely: 1. initial investigation; 2. design / design; 3. construction / realization; 4. test, evaluation \& revision; 5. implementation.

The development process to obtain a valid Brain Gym-Based Computer Application Learning Model, then carried out validation activities on the model book, learning tools, and research instruments needed. The development process to obtain a practical and effective Brain Gym-Based Computer Application Learning Model, pre-survey, pretesting, field trial and implementation activities were carried out using the learning tools and instruments developed. The development of a brain exercise-based computer application learning model is carried out following the development stages as a result of the modification of the development model proposed by Plomp, then successively describes the activities carried out in each development phase as follows: The flow of learning model development can be seen in the figure following: 


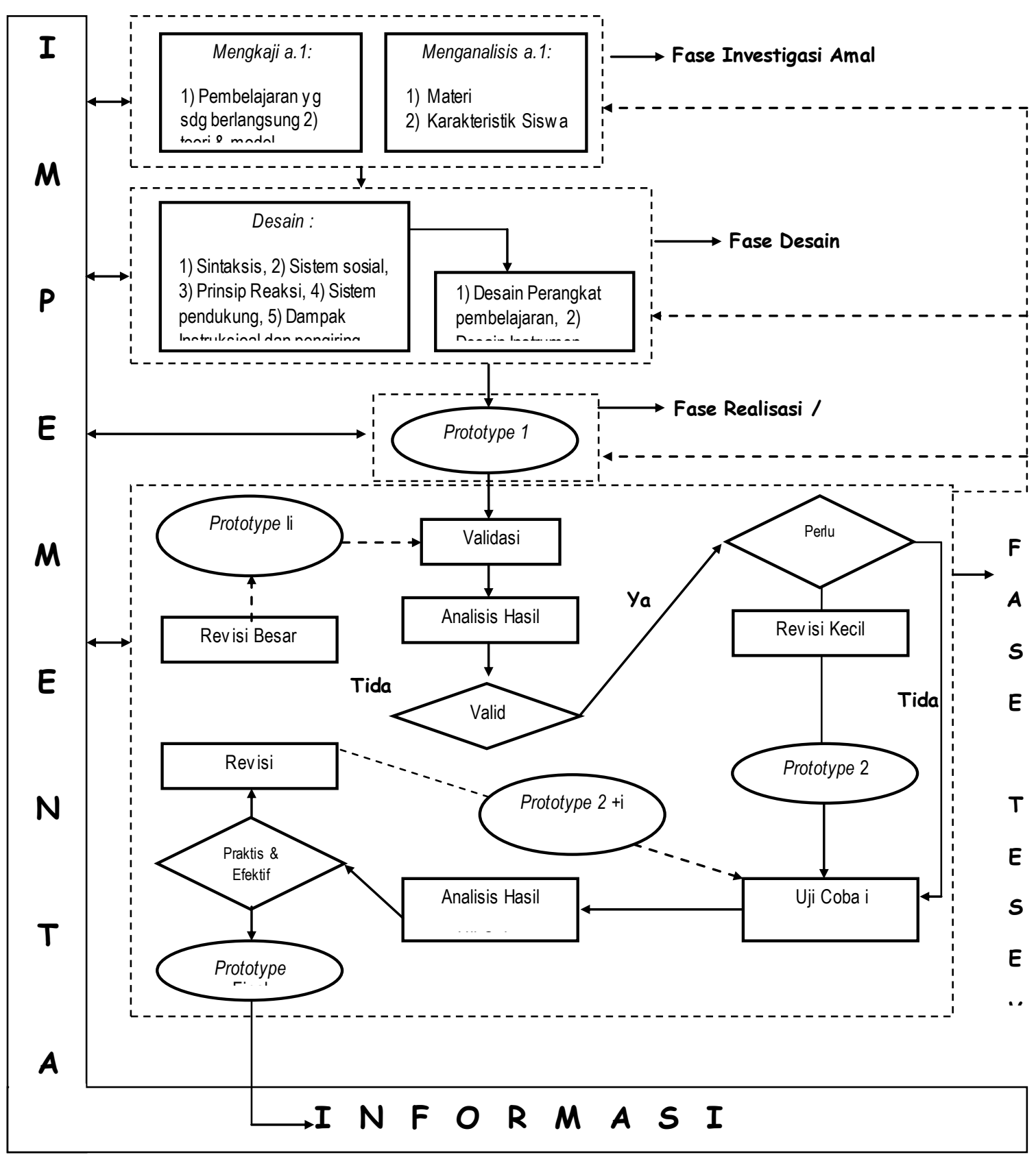

Figure 1. Image of Plomp Model Learning Development Flow (Wahyu Widada, 2012: 35)

Learning model development products are said to have good quality, if they meet the aspects of validity, practicality and effectiveness. After obtaining data from interviews and diaries, they are analyzed logically, namely analysis based on logical reasoning. After obtaining data from interviews and diaries, they are analyzed logically, namely analysis based on logical reasoning (Wahyu Widada: 2012: 36). 


\section{Discussion}

Eric Jensen (2011), one of the most enjoyable fields in the world is brain exercise Keeping up with the boom in brain gym for two decades has proved challenging, but smart educators apply the findings to ever-growing success. The result is a learning approach that is more suited to how the brain learns best naturally.

As a reference in the process of developing models and learning tools, this refers to a three-stage trial which includes expert testing, empirical testing and field testing which begins with the initial investigation stage, the design stage.

The description of the series of the process of developing learning models and tools starting from Phase-1, namely the initial investigation to the three-stage trial, is as follows:

The learning model developed is a computer application learning model based on brain exercise. The learning model was developed based on the results of the initial investigation of the learning model carried out on schools which included: students, lecturers, course materials, school support capacity, and the curriculum used.

From the results of initial investigations that have been carried out at Dehasen Bengkulu University, information is obtained in the form of the fact that currently there are still many lecturers in computer applications who prefer to use teacher center learning and lecturers who still use the threat system. Lecturers still use the lecture system so that students become good listeners and there are also students who do not get anything because they are very bored with the learning system. This way of teaching results in a low level of comprehension in optimizing the brain system for learning. Students are not faced that they are thirsty for learning but they still think that they only have to get high grades by forced to.

Eric Jensen (2011), Brain-based education is best understood in three ways, namely engagement, strategy and principles. Brain-based education is an engagement strategy that is based on principles derived from a single understanding of the brain. Brain-based education considers how the brain learns optimally.

So the researcher sees the need for efforts to develop learning models that encourage students to optimize their brain work systems. Maybe so far it has been stated that the most important thing is that students achieve the highest score in the exam, but this does not impact students being able to actively participate in the classroom, both mentally and physically, or take action or real activities (hands on) which are expected to improve their ability optimizing the brain by producing humans who are happy and able to adapt, can think well, care about others and are innovative.

Activities undertaken include: (1) the demands of the environment and society on learning computer applications, (2) student conditions which include: student activities during learning, the ability to understand concepts and problem solving, (3) lecturer conditions, and (4) curriculum analysis, namely , material analysis (identifying, detailing, and systematically drafting concepts for organizing subject matter), formulating basic competencies related to the needs of society and the environment.

The results of the initial investigation of the computer application learning tools used by computer application lecturers showed that the lecturers had not used brain exercisebased computer application learning devices.

Based on the results of the student analysis conducted by the researcher, it was found that the average age of students at Dehasen Bengkulu University was generally between 17 
and 19 years old. To meet the demands of learning that can make students learn actively, learning that will help students solve problems, and learning that connects parts of computer applications with other courses and problems in students' daily lives, as well as preparing an environment that allows students to obtain learning experiences, as well as providing an adequate model environment for the brain or brain's preferred system.

The social system states the roles and relationships of teachers and students, as well as the types of norms that are recommended (Joiece and Weill, 1992). Lecturers and students stick together to create a positive emotional environment, which is in accordance with the brain exercise-based learning model. In this activity, the Lecturer phase gives problems to students, Lecturer responds to students who ask questions, the lecturer supervises students and goes around the class and encourages students and lecturers to discuss with students to conclude the material being studied where this activity is in accordance with the brain exercise-based learning strategy that will make new learning connections in the brain.

According to Slavin, the effectiveness of learning consists of four indicators, namely the quality of learning (quality of instruction), intensive (incentives), and time (Wahyu Widada, 2012: 98).

In the learning model based on exercise, the teacher's brain becomes the facilitator, conductor and moderator. According to (Wahyu Widada, 2012: 20) as a facilitator, the teacher plays a role in providing and preparing learning resources for students to learn and providing guidance to students to be able to learn and construct their knowledge optimally. As a conductor, the teacher plays a role in regulating and encouraging each student in their learning activities. Meanwhile, the teacher moderator leads the class discussion, arranges the mechanism so that the class discussion runs well.

From the description above, it can be concluded that in the learning model based on brain exercise, the lecturer acts as a facilitator by preparing learning resources, directing students in completing LKM, helping students in understanding learning resources and constructing student knowledge to develop optimally.

The principle of reaction is related to how the teacher pays attention to and treats students as well as the way the teacher responds, responds to questions, answers, responses or what students do (Wahyu Widada, 2012: 106).

Based on the above description, the principle of reaction is that the Lecturer gives problems to students by attracting the attention of students and the teacher tries to make students active in learning activities, then explains the steps that students must do then the Lecturer presents the material with Ms. Power Points with attractive media displays, Lecturers with students discussing together and Lecturers try to create a sense of joy in students, Lecturers provide feedback in the form of values and awards to students because until the end of learning Lecturers and students continue to create a positive emotional environment.

The learning model support system is all the suggestions, materials and tools needed to apply the learning model. In the learning model with a brain exercise based learning model that needs to be prepared by the lecturer, it is a lesson plan, student activity sheets, evaluation tools, student books, question grids, student assessment questionnaires and the required learning media.

In the Brain Exercise based computer application learning model and its learning devices, after being declared valid based on expert and practitioner assessments, to see its practicality and effectiveness, two field trials were conducted. Field trials were carried out on students. After being validated and declared valid, the Brain Exercise Based Learning model and research tools and instruments became prototype 1 and could be tested. Tests 
were carried out on PKOM students at Dehasen University Bengkulu, to get prototype 2 of the model.

Table 1. The Results of Data Analys is

\begin{tabular}{|c|c|c|c|c|}
\hline \multirow[b]{2}{*}{ No. } & \multirow[b]{2}{*}{ Name } & \multicolumn{2}{|c|}{ Proporsi } & \multirow[t]{2}{*}{$T P S$} \\
\hline & & $U 1$ & $U 2$ & \\
\hline 1 & $A H$ & 0.18 & 0,90 & Very High \\
\hline 2 & $A R$ & 0.12 & 0,80 & High \\
\hline 3 & $A S$ & 0.16 & 0,84 & High \\
\hline 4 & $A U$ & 0.12 & 0,82 & High \\
\hline 5 & $F A$ & 0.12 & 0,84 & High \\
\hline 6 & $I B$ & 0.12 & 0,50 & Low \\
\hline 7 & $R P$ & 0.12 & 0,84 & High \\
\hline 8 & $Q H$ & 0.20 & 0,90 & Very High \\
\hline 9 & $E Q$ & 0.12 & 0,84 & High \\
\hline 10 & $I W$ & 0.12 & 0,78 & Moderate \\
\hline 11 & $G R$ & 0.12 & 0,90 & Very High \\
\hline 12 & $I Y$ & 0.20 & 0,80 & High \\
\hline 13 & $I A$ & 0.20 & 0,59 & Low \\
\hline 14 & $P S$ & 0.16 & 0,80 & High \\
\hline 15 & $\overline{P R}$ & 0.12 & 0,52 & Low \\
\hline 16 & $V S$ & 0.16 & 0,74 & Moderate \\
\hline 17 & $\overline{S N}$ & 0.20 & 0,90 & Very High \\
\hline 18 & $A W$ & 0,12 & 0,54 & Low \\
\hline \multicolumn{2}{|c|}{ Average } & 0,12 & 0,77 & High \\
\hline
\end{tabular}

The results of data analysis in the table above show that classically, the average level of student mastery of the material is high with the proportion of mastery of 0.77 or $77 \%$. Individually, many students who have a very high mastery level are 4 students, 8 students are high, 2 students are medium and 4 students have a low or low mastery level.

Based on the results of trials conducted 2 times which are limited trials in this study, it can be concluded that all aspects determined to state that the learning model and all learning tools developed are practical and effective have been fulfilled, so the development 
cycle to get a learning model that is practical and effective has ended. We can see based on chapter III which has been formulated, that a development learning model will be effective if it meets the criteria of high student activity in learning, student learning outcomes are classified as good, at least $85 \%$ of students have positive responses. Based on the results of the analysis, the model development can be said to be effective, because it has met the three criteria. More than $85 \%$ of students gave positive responses, learning outcomes were in good categories and student activity was high.

Based on the results of expert and practitioner assessments as well as the results of trial data analysis 2, it can be concluded that all aspects determined to state that the learning model and learning tools developed are practical and effective have been fulfilled, so the development cycle is to obtain a practical and effective has ended. But even though all the criteria are met, there are several revisions that must be made to get the final prototype. The revisions made are related to the use of language in model books and student activity sheets. After the revision was carried out, a final prototype was obtained, which is a valid, practical, and effective computer-based learning model for brain exercise, along with all related learning tools and research instruments, but there is still a need for revision to get the final prototype. Revisions were made to the language of the model books and student activity sheets to make them better. After being revised, a final prototype will be obtained, namely a learning model based on brain exercise that is valid, effective and practical.

\section{Conclusion}

Based on the results of research and discussion, it was concluded that a valid, practical and effective Brain exercise-based learning model was produced in understanding the concept of the computer application whose syntax is a) introduction, b) core activities include (i) problem-giving phase, (ii) investigation phase, ( iii) group discussion phase, (iv) class discussion phase, (v) application phase, c) closing.

\section{References}

Eric Jensen.2011. Pembelajaran Berbasis Otak. Jakarta:PT.Indeks

Judy Willis. 2010. Strategi Pembelajaran Efektif Berbasis Riset Otak. Yogyakarta: Mitra Media.

Khairani, S., Suyanti, R.D., and Saragi, D. (2020). The Influence of Problem Based Learning (PBL) Model Collaborative and Learning Motivation Based on Students' Critical Thinking Ability Science Subjects in Class V State Elementary School 105390 Island Image. Budapest International Research and Critics in Linguistics and Education (BirLE) Journal Vol 3 (3): 1581-1590.

Lehawati, Sutopo, A., Winahyu, S. (2020). The Effect of Cooperative Type Number Heads Together and Concept Mapping Learning Models on Student's Learning Activity and Student Learning Outcomes in Class V Science Study of SD Negeri 11 Rantau Selatan. Budapest International Research and Critics in Linguistics and Education (BirLE) Journal Vol 3 (4): 1983-1991.

Nurjanah, S., Daulay, S., and Ansari, K. (2020). The Development of the Assurance Relevance Interest Assessment Satisfaction (Arias) Collaborative Jigsaw Collaborative Learning Model in Writing News Text Class 8 Junior High School 
State 06 Medan. Budapest International Research and Critics in Linguistics and Education (BirLE) Journal Vol 3 (1): 583-590.

Matthew B Miles and A. Michael Huberman. 1994. Qualitative Data Analysis. London: Sage Publication

Mega Teguh Budiarto. 2006. Profil Abstraksi Siswa SMP dalam mengkonstruksi Hubungan Antarsegiempat. Disertasi doctor, tidak diterbitkan, Universitas Negeri Surabaya

Simanjuntak, L., Sriadhi, and Saragi, D. (2020). The Effect of Project Based Learning Models and Learning Motivation on Civics Learning Results in 4th Grade Primary School 106163 Percut Sei Tuan. Budapest International Research and Critics in Linguistics and Education (BirLE) Journal Vol 3 (3): 1509-1520.

Sugiyono. 2011. Metode Penelitian Pendidikan Pendekatan Kuantitatif, Kualitatif dan R \& D. Bandung: Alfabeta.

Wahyu Widada. 2003. Struktur Representasi Pengetahuan Mahasiswa tentang Permasalahan Grafik Fungsi dan Kekonvergenan Deret Tak Hingga pada Kalukulus. Disertasi tidak diterbitkan. Surabaya: UNESA

Wahyu Widada. 2004. Dekomposisi Genetik (Teori APOS pada pembelajaran Kalkulus). Bengkulu: Jurnal Inspirasi, Monograpi 1.

Wahyu Widada. 2011. Eksistensi Exended Level Trans pada Pelevelan Perkembangan Kognitif Mahasiswa Teori Graph. Bengkulu: Program Pascasarjana Pendidikan Matematika FKIP UNIB.

Wahyu Widada. 2012. Model Pendidikan Karakter Melalui Pembelajaran yang Membumi. Bengkulu: S2PMAT FKIP UNIB. 